\title{
オージェ電子分光法
}

田中 幸基 ${ }^{\mathrm{a}}$, 新谷 龍二 ${ }^{\mathrm{b}}$, 山本 広一 $^{\mathrm{a}}$

${ }^{\mathrm{a}}$ 日鉄住金テクノロジー(株) 富津事業所 ( 293-0011 千葉県富津市新富 20-1)

${ }^{\mathrm{b}}$ 日鉄住金テクノロジー(株) 尼崎事業所 ( T 660-0891 兵庫県尼崎市扶桑町 1-8)

\section{Auger Electron Spectrometry}

\section{Koki TANAKA $^{\text {a }}$, Ryuji SHINYA ${ }^{\mathrm{b}}$ and Kohichi YAMAMOTO}

${ }^{a}$ Futtsu Unit, NIPPON STEEL \& SUMIKIN TECHNOLOGY Co., Ltd.(20-1, Shintomi, Futtsu-shi, Chiba 293-0011)

${ }^{\mathrm{b}}$ Amagasaki Unit, NIPPON STEEL \& SUMIKIN TECHNOLOGY Co., Ltd.(1-8, Fuso-cho, Amagasaki-shi, Hyogo 660-0891)

Keywords : Electron Spectrometry, Surface Analysis, Depth Profile, Segregation, Precipitate

\section{1. はじめに}

オージェ電子分光法(Auger Electron Spectrometry または Auger Electron Spectroscopy, AES)は, 加速した電子を分析 試料に照射し, $1 \sim 2 \mathrm{~nm}$ 程度の表面層から放出される元素 固有のエネルギーを持つオージェ電子を検出することで, 試 料の表面に存在する元素の種類と量に関する情報を得る分析 法である。数十 $\mathrm{nm}$ 程度の微小領域の元素分析, 元素の面内 分布, 深さ方向分布が分析でき, 試料表面の組成, 微小析出 物の成分, 表面㧍よび界面に扔ける偏析元素, 被膜を有する 試料では被膜と基材のそれぞれの成分, 被膜と基材の界面に おける元素分布, 拡散状態, 析出相などの分析に有効な方法 である。また，オージェ電子のエネルギースペクトルを詳し く解析することで, 元素の化学状態に関する情報も得られる。 本稿では AES の原理と特徴, 応用事例を紹介する。

\section{2. 原理と特徵}

\section{1 オージェ電子分光法の原理}

固体に電子を照射すると, 固体内原子の内殼電子が励起さ れて空孔が生じ, 直ちに外殼の電子で満たされる。このとき 内殼と外殼のエネルギー差は, 特性 X 線の放出か, または, 電子の放出のどちらか一方で消費される。放出される電子は, 現象の発見者である Pierre Victor Augerにちなんでオージェ 電子と呼ばれている。

図 1 に原理の概要を示すが, この例では, 電子照射で生じ た $\mathrm{K}$ 殼の空孔を $\mathrm{L}_{2}$ 殼の電子が満たし，その際のエネルギー 差によって $\mathrm{L}_{3}$ 殼からオージェ電子が放出される様子を示し ている。このオージェ電子は $\mathrm{KL}_{2} \mathrm{~L}_{3}$ と表記される。 $\mathrm{KL}_{2} \mathrm{~L}_{3}$ オー ジェ電子の運動エネルギー $\mathrm{E}_{\mathrm{A}}$ は，（1)式で表すことができる。

$$
\mathrm{E}_{\mathrm{A}}=\mathrm{E}_{\mathrm{K}}-\mathrm{E}_{\mathrm{L} 2}-\mathrm{E}_{\mathrm{L} 3}-\phi_{\mathrm{S}}
$$

ここで， $\mathrm{E}_{\mathrm{K}}, \mathrm{E}_{\mathrm{L} 2}, \mathrm{E}_{\mathrm{L} 3}$ は, $\mathrm{K}, \mathrm{L}_{2}, \mathrm{~L}_{3}$ 準位のエネルギー, $\phi_{\mathrm{S}}$ は試料の仕事関数である。

オージェ電子の運動エネルギー $\mathrm{E}_{\mathrm{A}}$ は図 1 に示したように
電子のエネルギー準位にのみ依存しており，照射する電子の 加速エネルギーには依存しない。元素の電子の束縛エネル ギーは既知なので, 測定したオージェ電子のエネルギーから 元素を同定できる。オージェ電子のエネルギーについては,

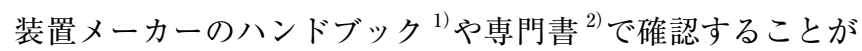
できる。通常, 表面分析に応用するオージェ電子は約 20 $2500 \mathrm{eV}$ 程度の運動エネルギーを持つが, この範囲の運動エ ネルギーを持つ電子は固体中で吸収され, 約 $5 \mathrm{~nm}$ より深い 位置で発生したオージェ電子は試料表面から脱出できない。 検出されるオージェ電子は, 試料表面から $0.3 \sim 5 \mathrm{~nm}$ 程度 の深さ範囲に存在する元素から放出されたものである。上述 したように, オージェ電子の運動エネルギーは照射する電子 の加速エネルギーには依存しないので, 加速電圧を大きくし ても, オージェ電子の脱出深さが深くなることはない。すな わち, AES が検出する元素は試料表面だけの元素であって, 約 $5 \mathrm{~nm}$ よりも梁い部分の元素については検出しないので, 表面にのみ感度が高い分析方法となる。オージェ電子の検出

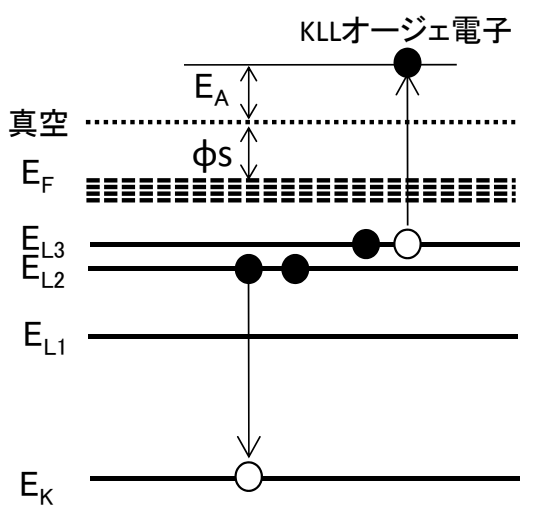

$$
\begin{aligned}
& \text { KLLオージェ電子分光の運動エネルギー } \\
& E_{A}=E_{K}-E_{L 2}-E_{L 3}-\phi S
\end{aligned}
$$

図1 オージェ電子の発生 
深さについての詳細は文献 2)，3）を参照されたい。

元素から放出されるオージェ電子の電流は, (2)式であら わされる。

$$
I=I_{\mathrm{p}} \cdot \sigma \cdot(1-X) \cdot \lambda \cdot C \cdot(1+B) \cdot T
$$

$I_{\mathrm{p}}$ : 照射電子の電流, $\sigma$ : イオン化断面積, $X$ : 蛍光収 率, $\lambda$ :電子の平均自由行程, $C$ : 元素の表面濃度, $B$ : 背面散乱因子, $T:$ 分析器の透過率

蛍光収率 $X$ は, 電子照射で生じた空孔を外殼電子が埋め る際に $X$ 線が放出される確率で, $1-X$ はオージェ電子が放 出される確率に相当する。(2) 式が示すように, オージェ電 子の電流は試料表面の元素含有量 $C$ に比例するので, 電子 検出器で計測されるオージェ信号強度から元素の表面濃度が 分かる。蛍光収率 $X$ は原子番号が大きい元素ほど大きく, 一方，オージェ電子の放出率は軽元素ほど大きい。そのため, AES は軽元素ほど高感度で検出することができる。走査電 子顕微鏡 (Scanning Electron Microscope, SEM)で成分分析をす る場合, エネルギー分散型 X線分析器 (Energy Dispersive X-ray Spectrometry, EDS)が用いられるが, EDS では, B，C，N， O などの軽元素は感度が低く，検出されにくい元素である。 AES ではこれらの軽元素が容易に検出可能である。特に EDS ではできない Li の分析が可能で, Li イオン電池の電極 材料の分析に応用されている ${ }^{3)}$ 。なお, オージェ電子の放出 には上記のように 3 個の電子が関与するため, H と $\mathrm{He}$ は分 析できない。

\section{2 AES 装置}

AES 分析装置は, 主として電子銃と電子光学系, 試料室, 電子分光装置とイオンエッチング用のイオン銃から構成され ている。

電子銃は, タングステンフィラメントを通電加熱し, 発生 する熱電子を電極に印加した電圧によって引き出す。電子放 出源として高融点で仕事関数が低い六ホウ化ランタン $\left(\mathrm{LaB}_{6}\right)$ を用いた電子銃や, さらに高輝度の電子源である フィールドエミッション電子銃を用いた装置(FE-AES)があ る。電子銃から放出された電子は, 電子光学系で数 $\mathrm{kV}$ $25 \mathrm{kV}$ 程度の電圧で加速され, レンズで直径数 $\mathrm{nm}$ 程度のビー ムに集束されて試料に照射される。

オージェ電子の測定方法には, 主に図 2 と図 3 に示すよう な 2 通りの方法がある。図 2 は同軸円筒鏡型の電子分光器で, 外側の円筒と内側の円筒の間に電圧を印加して, 特定のエネ ルギーを持つオージェ電子を電子検出器に導くことでエネル ギー分析を行う。分光器の中心軸上に電子銃を配置し， 360 度全方位に放出されるオージェ電子を取り込むため, 分析結 果が試料形状や試料の傾斜角の影響を受けにくいという特徴 がある。

図 3 は同心半球型の電子分光器である。半径が大小 2 つの 半球を電極とした構造の分光器で, 高いエネルギー分解能で オージェ電子を検出でき, 化学結合状態によるオージェ電子 のピーク形状の変化をとらえることが可能である。

AES 装置には, Arイオン銃が搭載されており, $1 \sim 5 \mathrm{kV}$ 程度の電圧で加速した $\mathrm{Ar}$ イオンを試料に照射し，スパッタ リング現象を使って表面を剥離し，清浄な試料面を露出させ る場合や，元素の深さ方向分布を測定する場合に用いられる。
試料室はターボ分子ポンプやスパッタイオンポンプ, チタ ンゲッターポンプを組み合わせた超高真空排気装置で排気さ れて, $1 \times 10^{-8} \mathrm{~Pa}$ 以下の圧力に維持されている。

AES は表面に敏感な分析法であるので，表面を污染しな いように試料の取り扱いには細心の注意が必要である。通常, 大気に触れた試料は表面に水や炭化水素などの分子を吸着し ている。オージェ電子はこの吸着層に吸収されて強度が大き く減少するため, 試料表面を Arイオンでエッチングして, 吸着層を除去することが必要な場合が多い。

試料室の中は真空排気しても, 気体分子が残留しており, その量は試料室中の圧力に比例し, 圧力が高いほど試料表面 に吸着する気体分子の量は多くなる。試料室中を超高真空に 保てない場合, 残留気体の分子が試料表面に吸着し, オージェ 電子がこの吸着層に吸収され検出されなくなる。また， $\mathrm{Ar}$ イオンでエッチングして清浄面を得ても, 試料表面は直ちに 残留気体の分子で覆われ，水分子や炭化水素分子に由来する C や O からのオージェ信号が常に検出されてしまうことに なる。前述したように, AES は C,O に対する感度が高いので, これらの元素を分析する目的で用いることが多いが, 残留気 体の分子が吸着すると, 本来目的とした試料中の $\mathrm{C}, \mathrm{O}$ の分 析が困難になる。そのため, 試料室内は超高真空に保つ必要 がある。油脂や水分が付着した試料や多孔質の試料は，真空

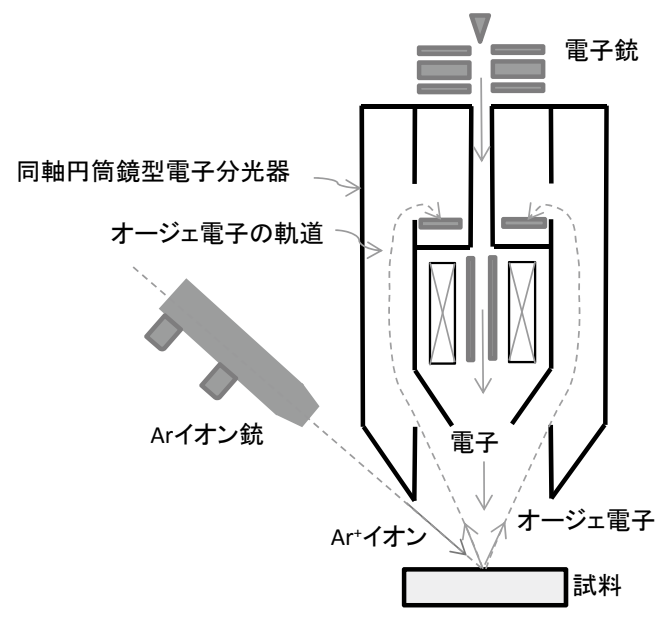

図 2 同軸円筒鏡型オージェ電子分光器

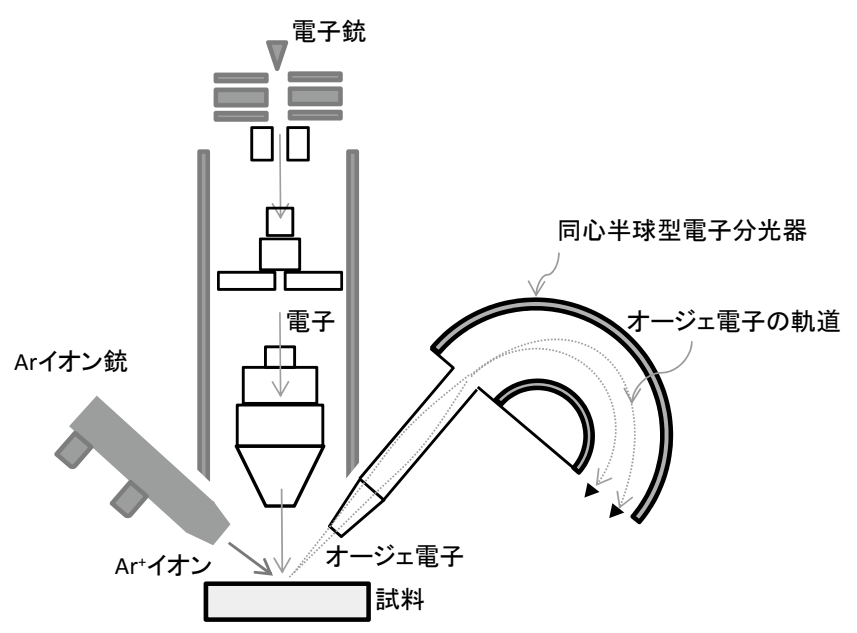

図 3 同心半球型オージェ電子分光器 
中で長時間にわたってガスを放出し続け, 試料室内の圧力が 十分下がらない場合がある。分析の前に試料を脱脂洗浄し, 予備排気室で十分にガスを放出した後, 試料室に入れるなど の工夫が必要である。

また，試料を直接素手で扱うと皮脂が付着して分析の妨げ になるので，常にポリエチレン製やビニール製等の清浄な使 い捨て手袋を装着した手で扱うことが必要である。ピンセッ トやドライバーなどの器具類も, 脱脂洗浄したものを使うこ とがのぞましい。試料を識別するための記号を，試料に直接 書くことは避けなければならない。

\section{3 分析方法}

図 4 にオージェ電子信号の例として鋼板表面に電子を照射 して得られるオージェ電子スペクトルの例を示す。試料から 放出されるオージェ電子の数は, 電子照射で発生する散乱電 子や 2 次電子の $0.1 \%$ 程度以下しかなく, オージェ電子は散 乱電子と 2 次電子によってつくられるバックグラウンドの上 に微小な信号であらわれる。そのため, オージェ電子の信号 は図 4 のように微分スペクトルであらわされることが多い。 前述したように固体中のオージェ電子の平均自由行程は数 $\mathrm{nm}$ 以下であるために，それよりも深い部分の元素情報は含 まれていない。

定量分析を行うには，得られたオージェ電子スペクトルか ら以下の (3) 式によって原子濃度を求める。

$$
X_{i}=\frac{N_{i} / S_{i}}{\sum_{j=1}^{N} N_{j} / S_{j}}
$$

ただし， $X_{i}$ は元素 $i$ の原子濃度, $N_{j}$ は $j$ 元素のオージェ電 子の信号強度 (微分曲線の山と谷の計数の差), $S_{j}$ は元素 $j$ の 感度係数である。実際の定量には, 試料の組成の影響など $(3)$ 式に補正を加える必要があるが, その詳細については専門書 を参照されたい。市販の装置には，オージェ電子の信号強度 から組成を求めるためのソフトウエアが付属しており，手軽 に定量值を求めることができるが, 精度はあまり高くないと されている。

図 4 にはオージェ電子の信号強度から定量化した各元素の 原子数濃度を示したが, 試料を測定室に入れた直後にオー

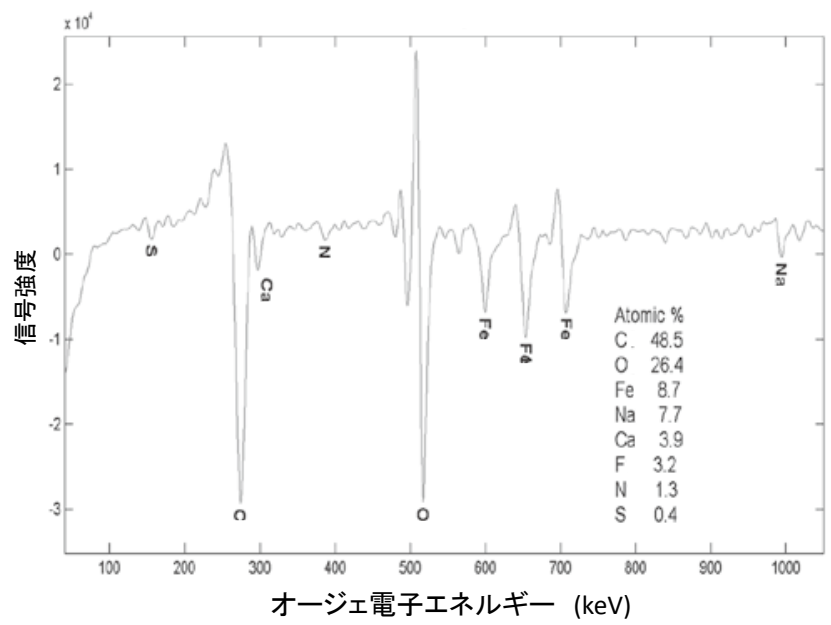

図 4 AES で得られるオージェ電子信号の例 鋼板試料表面からのオージェ電子のエネルギー分布
ジェ電子を測定すると，この例のように C や $\mathrm{O}$ からのオー ジェ電子信号が強く表れることが多い。これは試料中に含有 される $\mathrm{C} や \mathrm{O}$ に由来するものではなく, 試料表面に形成さ れた酸化物や吸着分子の層からの信号である。しかし, $\mathrm{Ar}$ イオンにより表面をスパッタリングして, 清浄面を得た状態 でオージェ電子スペクトルを測定すると, 後述する優先ス パッタリングが起きにくい試料では，化学組成にほぼ等しい 定量值が得られる。精度のよい定量値が必要な場合には, 煩 雑ではあるが標準試料を用いることによって可能である。 AES の感度は，他の分析法と比較すると，あまり高くない。 先述したように，オージェ電子の信号は $\mathrm{S} / \mathrm{N}$ 比が低いので, 試料や元素にもよるが定量下限は $1 \sim 2 \%$ 程度である。

\section{4 オージェ電子分光法の特徵}

表面分析では目的に応じて最適な方法を選択して用いるこ とが重要である。原理や特徵を AES と比較するため, 他の 分析法についても簡単に触れる ${ }^{5)}$ 。

電子プローブX線分析法(Electron Probe X-ray Micro Analysis, EPMA)は，AES と同様に細く絞った電子をプローブとして用 いる分析方法で, 電子照射で励起された原子から放出される 元素特有の波長をもつ特性 X 線を計測することで元素分析を 行う。検出する信号が異なるだけで, AES と EPMA はよく似 た方法であるが, 特性 X 線はオージェ電子と比較して固体中 の透過率が高いので, EPMA は試料表面から約 $1 \mu \mathrm{m}$ 程度ま での深い部分からの情報が得られる。また，固体中での電子 の拡散により, プローブ径よりも広い範囲から特性 X 線が放 出される。一方，オージェ電子の放出範囲は特性 X 線のそれ よりも浅く狭いので, AES は EPMAよりも浅い最表面のみの 情報を得たい場合や，深さ方向の元素分布を測定する場合に 有効である。特に, 電子ビームが $5 \mathrm{~nm}$ 程度まで集束される FE-AES では, 空間分解能が電子ビーム径と同程度であり, 数 十 $\mathrm{nm}$ 程度の微小領域の分析が可能である。

深さ方向の元素分布を測定するための分析方法として, グロー 放電発光分析法 (Glow Discharge Optical Emission Spectrometry, GDS）がある。GDS は，バルクの成分定量のほか, 深さ方向 の元素分布を測定する目的で用いられることが多く, 最表面 ～数 $\mathrm{nm}$ あるいは $100 \mu \mathrm{m}$ を超える深さまで, 深さ方向の元 素分布を短時間で定量できる。金属材料だけでなく,セラミッ クスなどの絶縁物でも分析が可能で, 酸化スケール, 表面コー ティング, めっきなどの被膜組成や界面の元素分析に有効で ある。分析できる元素は水素からウランまで幅広く, 数 $\mathrm{ppm}$ 〜数十 ppm 程度の微量元素を検出できる。分析領域のサイ ズは通常, 直径が数 $\mathrm{mm}$ で, 特定の微小領域の分析には不 向きであるが，被膜等の平均組成については代表性の良い分 析結果が得られる。GDS は超高真空が不要で, 装置の操作 や保守が容易である。

微小領域で, 高感度の分析が可能な方法として二次イオン 質量分析法 (Secondary Ion Mass Spectrometry, SIMS)がある。 SIMS は，イオンを試料に照射し，スパッタリングによって 真空中に放出された粒子の質量と強度を測定することで，表 面の元素分析を行う方法である。SIMS は水素をはじめほと んどの元素を高感度で検出することができ, 深さ方向の元素 分布が測定可能である。 
SIMS では試料に照射するイオンを 1 次イオン， スパッタ リングで放出される粒子イオンを 2 次イオンと呼ぶ。装置は 主に 1 次イオン照射装置と 2 次イオン質量分析装置から構成 されており，1次イオンとして Cs（セシウム）イオンが用い られることが多い。2 次イオン質量分析装置には, 磁場偏向 型質量分析装置, 四重極質量分析装置, 飛行時間型質量分析 装置などのタイプがある。最近では $\mathrm{Ga}$ (ガリウム)の集束イ オンビームにより, $40 \mathrm{~nm}$ 程度の分解能での元素マッピング も可能となっている。SIMS の深さ方向の分解能は数十 $\mathrm{nm}$ 程度, 空間分解能は数 $\mu \mathrm{m}$ 程度である。検出下限は, 元素に よっては ppb レベルの極微量元素の検出が可能である。定量 は適切な標準試料が得られれば可能であるが, 例えば試料の 酸化物の影響を受けやすいなど, 高精度の定量を目的とする 場合には注意が必要である。

X 線光電子分光法 (X-ray Photoelectron Spectrometry または X-ray Photoelectron Specroscopy, XPS) は, AES と同様, 電子 分光による表面分析法である。XPS は，X 線を試料に照射し， 試料中の原子から放出される電子 (光電子)のエネルギー分析 を行うことで試料表面の組成を定量する分析法である。光電 子の運動エネルギーから電子の結合エネルギー, すなわち元 素の化学状態に関する情報が得られる。結合エネルギーは元 素固有の值であるので試料中の含有元素が同定でき, 光電子 の強度から含有量が定量できる。また，化合物では，原子間 の価電子の移動に伴う電荷分布の変化により内殼電子の結合

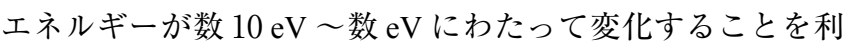
用して化学状態が推定できる。一般的にはイオン結合性が増 加し, 高酸化状態になるほど結合エネルギーが増加する傾向 がある。

光電子の運動エネルギーは励起 $X$ 線のエネルギーに依存 するが， $\mathrm{Al} \mathrm{K} \alpha$ 線を励起源とした場合， $1200 \mathrm{eV}$ 以下であり， 固体からの平均脱出深さは $1 \mathrm{~nm}$ 以下である。そのためXPS は試料の表面の元素のみを分析していることになる。プロー ブとしてX線を用いるので，分析領域のサイズは，実用的 には数十 $\mu \mathrm{m}$ 程度が最小である。定量下限は AES と同程度で, 1 ～ 2 原子数\%程度である。

上記のように, AES は各種表面分析法の中では比較的空間 分解能が高く, 表面敏感であるので, $1 \mu \mathrm{m}$ 以下の微小析出物 の成分分析, 粒界偏析元素の同定, $1 \mu \mathrm{m}$ 以下の薄い被膜の深 さ方向の分析を目的とする場合に有力な選択肢のひとつにな る。分析対象とする物質は, 金属以外にも, 半導体, セラミッ クス，金属酸化物などが分析可能である。ただし，絶縁物質 の分析には注意が必要である。絶縁物に電子を照射すると,

試料表面が帯電して, その影響でオージェ電子の運動エネル ギーが変化してしまい，正しい測定ができなくなってしまう。 また，集積回路の電極を分析する場合のように分析箇所は金 属であっても周囲が樹脂のような絶縁物で囲まれている場合 も同様である。絶縁物を分析する場合には, 試料の帯電を防 止する対策が必要である。EPMAの場合には, 試料表面に炭 素や金などの導電性物質を薄く蒸着することで絶縁物の分析 をしているが, AES の場合にはこの方法は使えない。AES では, 帯電防止策として試料を傾斜させる方法や, 低速の Ar イオン を照射することで帯電を中和する方法がある ${ }^{4)}$ 。
有機物質の分析は慎重に行う必要がある。電子照射によっ て試料状態が容易に変化するものは分析できないし, 電子照 射によって溶解して真空中にガスを放出するものは，装置を 污染して性能を劣化させてしまうため扱いが困難である。

\section{3. オージェ電子分光法の応用例}

図 5 に元素の深さ方向分布を測定した例として, PbSn 共 晶はんだの深さ方向分析を測定した例を示す ${ }^{5)}$ 。図 5 (1) は, 二次電子像観察による $\mathrm{PbSn}$ 共晶はんだの組織である。四角 で囲んだ部分 (a)，（b)はそれぞれ組成が異なり，(a) Pb リッ チ相と (b) Sn リッチ相に分離している。(a)，（b)それぞれに ついて, Arイオンでエッチングしつつ Pb と $\mathrm{Sn}, \mathrm{O}$ のオー ジェ電子スペクトルを測定し, 各元素の深さ方向分布を取得 した。図5(2)は図5(1)の(a)，（b）における O, Pb， Snの 深さ方向分布である。はんだの表面 $1.5 \mathrm{~nm}$ 程度に酸化物が

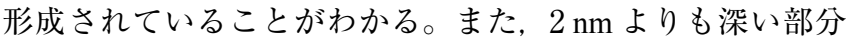
においては，(a) Pb リッチ相と（b）Snリッチ相，それぞれ の組成を示している。このような合金元素を定量する場合に

(1)

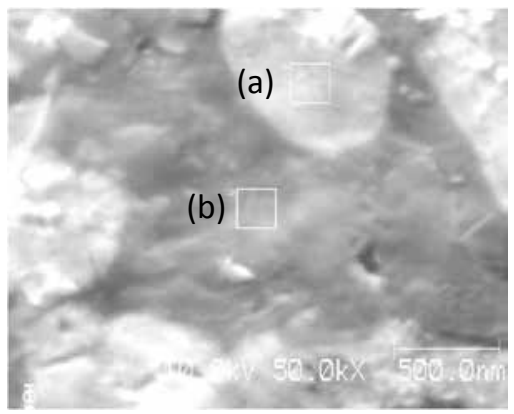

(2)
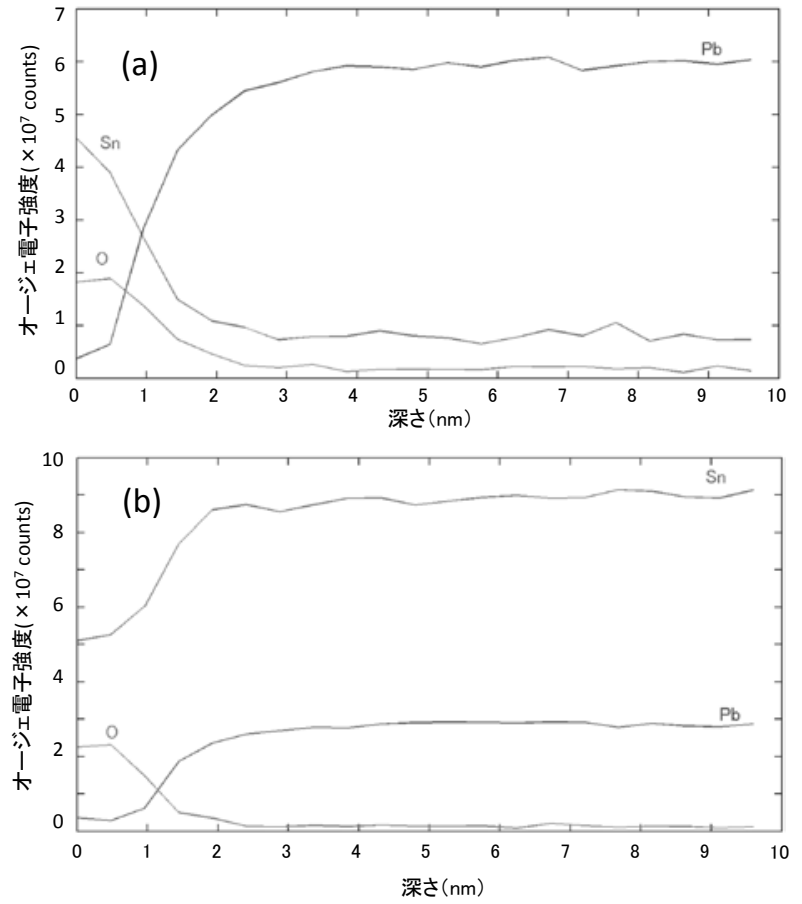

図 $5 \mathrm{SnPb}$ 共晶はんだの AES 分析

(1) $\mathrm{PbSn}$ 共晶はんだの 2 次電子像,

(2) (a)，(b)に打ける O , Sn， Pb の深さ方向分布 
気をつけなければならないのは, 元素によっては $\mathrm{Ar}$ イオン で優先的にスパッタされるため, バルク組成と異なる結果が 得られる場合があることである ${ }^{6)}$ 。

FE 電子銃を用いた AES では空間分解能が高いという特徵 を活かし, 試料の断面を研磨によって露出させ, 断面を横切 るように電子を走査しオージェ電子を測定することで元素の 深さ方向分布を測定することが可能である。Ar イオンエッ チングでは，数 $\mu \mathrm{m}$ 程度の深さまで掘り下げるには長時間を 要することと, Ar 照射量の増加と共に試料表面が荒れるので, 数百 $\mu \mathrm{m}$ を超える深さまで分析することは実用上困難である が, 集束イオンビーム加工 (Focused Ion Beam, FIB) 等で露出 させた断面を測定すれば，数百 $\mu \mathrm{m}$ 程度の深さ方向分析が可 能である。図 6 はその一例で, 試料は Si ウエハー基板にス パッ夕蒸着法で Ti 膜を形成し，さらに，その上に順に $\mathrm{Pd}$,

$\mathrm{Au}, \mathrm{Cr}, \mathrm{W}$ の層を形成した多層膜である。断面を FIB 加工 によって露出させ, $\mathrm{W}$ 層から $\mathrm{Si}$ 基板にかけて電子を走査し つつ各元素からのオージェ電子スペクトルを測定し, 深さ方 向の分布を得ている ${ }^{7)}$ 。

$\mathrm{P}, \mathrm{S}, \mathrm{Sn}, \mathrm{Sb}$ などは鋼の粒界に偏析しやすい元素で，粒 界脆化の原因になることが良く知られている。AES は粒界 脆化の原因となる元素を特定する分析に有効な手段である。 AES で粒界を分析するには，粒界面を露出させる必要がある。 そのためには, 試料に予めノッチ加工を加え, AES 装置の 試料室で液体窒素によって間接的に冷却し，外部から衝撃を 加えて破断する。破断した部分の破面の 2 次電子像を観察し て，粒界破面を選んで AES 分析を行う。分析は，通常，0 〜 $2000 \mathrm{eV}$ 程度のエネルギー範囲でオージェ電子スペクトル を測定して検出される元素を確認する。次に，粒界面上で電 子を走査し, 検出元素のオージェ電子信号によるマッピング 像を観察する。

図 7 は, 純鉄に添加した S の粒界偏析を調べた例である ${ }^{7)}$ 脆化した試料の粒界破面を AES 分析した結果，(a)に示すよ うに，S が粒界偏析していることが確認された。一方，硫化 物を形成しやすい $\mathrm{Al}, \mathrm{Ca}$ を添加した試料では，（b）に示し たように，S は検出されず粒界偏析が抑制されていることが 分かる。図 8 は, 鋼の粒界に偏析した P の存在状態を分析

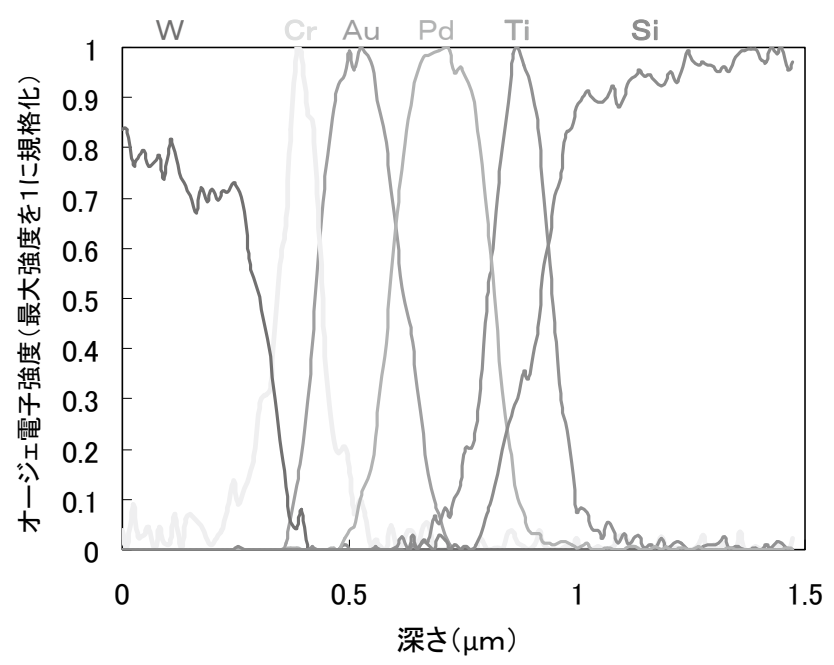

図 6 FIB 加工による薄膜の断面での深さ方向分析
した例で，P と Feについてマッピングを行った結果である ${ }^{5)}$ 。 粒界偏析した $\mathrm{P}$ は 1 原子層程度の厚さしかないが, AES は 表面敏感であるために元素マッピング像が観察できる。粒界 偏析による脆化対策として, 第 3 元素を添加し析出物を形成 することで粒界偏析が抑制できるが，析出物の形成状態と粒 界偏析状態を確認する目的でも AES は有効に活用できる。 図 7, 図 8 で示した粒界偏析元素を AES で分析するには, 試料を真空中で破断して粒界を露出させた後, 試料を大気に 暴露することなく AES 装置に導入することが必要である。 大気中で試料を破断すると，破断面には大気中のガス分子が 吸着し，オージェ電子が検出されなくなるためである。破断 面の分析を目的として, 試料室内で試料を破断する機構を備 えた AES 分析装置もある。

$\mathrm{Li}$ イオンバッテリの開発における電極材中の $\mathrm{Li}$ の分析に AES は有効な手段の一つであり, AES による Li の分析につ いて，堤らの報告がある ${ }^{8)}$ 。 Li からの KVVオージェ電子は, 運動エネルギーが低いので, バックグラウンドに埋もれて $\mathrm{S} / \mathrm{N}$ 比が低くなることと, 試料表面からのオージェ電子の脱 出深さが浅く，わずかな污染層で吸収されて検出が困難であ るため，XPS と比較して AESによる Li の分析は困難とされ てきた。堤らは AES と XPSによる Li の検出感度を検討し, $10 \mathrm{kV}, 10 \mathrm{nA}$ の電子照射による Li KVV オージェ電子の C KLL オージェ電子に対する強度比は 4 倍程度, 一方, $\mathrm{Al} \mathrm{Ka}$ $\mathrm{X}$ 線による $1 \mathrm{~S}_{1 / 2}$ 光電子の $\mathrm{C}$ に対する $\mathrm{Li}$ の強度比は $1 / 18$ 程 度であるので, 試料の前処理を十分注意して行うことで, AES による Li の分析は十分可能であるとしている。リチウ ムイオン電池材料に含まれる $\mathrm{Li}, \mathrm{C}, \mathrm{O}, \mathrm{Mn}, \mathrm{Co}, \mathrm{Ni}$, 蛍光 X 線分析法, XPS, AES, 走査電子顕微鏡で分析し, AES によって精度のよい結果が得られることを示している。

同心半球型電子分光器を備えた AES 装置では, オージェ 電子を高エネルギー分解能で測定でき, 化学結合状態による オージェ電子のエネルギーシフトを測定することができる。 これを応用することで, 微小領域の化学状態分析が可能とさ れている。AESによる化学状態分析については, 多くの検 討事例がありその可能性が示唆されている ${ }^{9), 10)}$ 。オージェ電

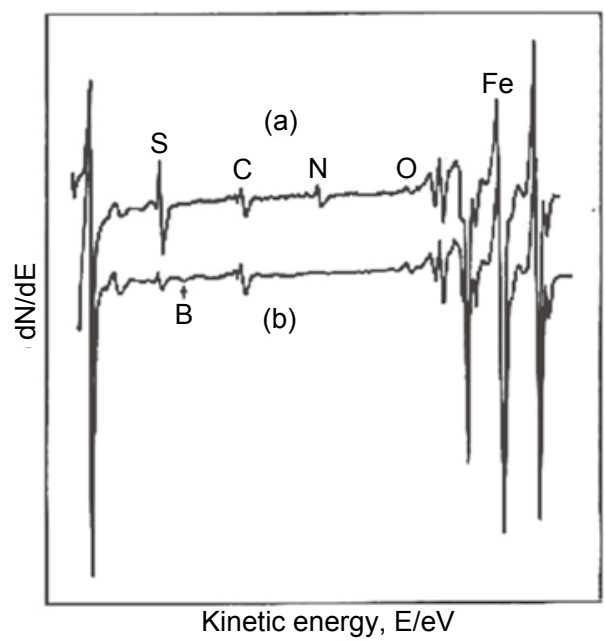

図7 硫黄を添加した純鉄の粒界破面の AES 分析 ${ }^{6)}$ (a) $\mathrm{Al}$ 無添加, (b) $\mathrm{Al}$ 添加 

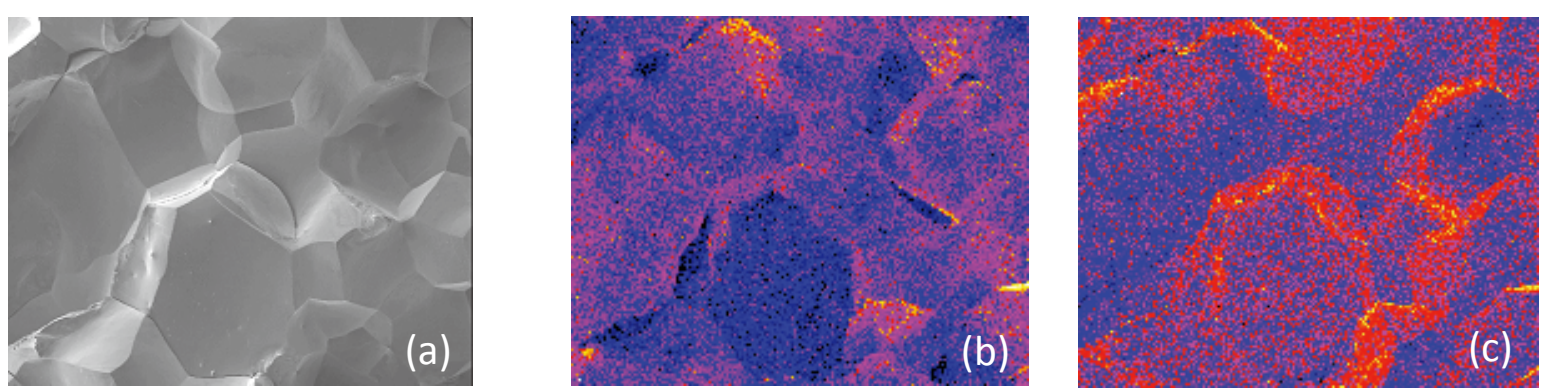

オージェ電子信号強度

図 8 鋼中に添加した $\mathrm{P}$ の粒界偏析の AES 分析 ${ }^{5}$

(a) 2 次電子像, (b) P の分布, (c) Feの分布

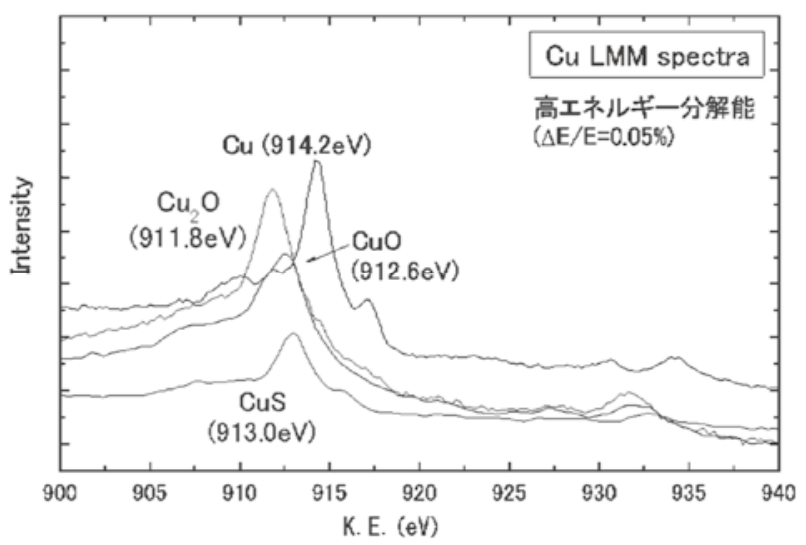

図 9 銅の化学状態と Cu LMM オージェ電子スペクトル ${ }^{11)}$

子の運動エネルギーは(1)式であらわされるが, 分析元素と 隣接元素との間の電子の共有状態によって, $\mathrm{E}_{\mathrm{K}}, \mathrm{E}_{\mathrm{L} 2}, \mathrm{E}_{\mathrm{L} 3}$ が それぞれ変化する。XPS では, 化学結合に伴う光電子スペ クトルの化学シフトは, 分析元素の 1 つの電子エネルギー準 位の変化によるので, 比較的理解しやすく, 分子軌道法によっ て化学シフトの計算が可能である ${ }^{11)}$ 。しかし, AESの化学 シフトは上記の 3 つのエルギー準位の変化が関係している ためXPSより複雑である。あらかじめ, 化学状態が既知の 純物質の AES スペクトルを測定しておき，分析試料の AES スペクトルと比較することによって化学状態を推定すること が多い。境は, $\mathrm{Cu}, \mathrm{CuO}, \mathrm{Cu}_{2} \mathrm{O}$ の $\mathrm{Cu} \mathrm{LMM}$ オージェスペク トルと $\mathrm{Cu} 2 \mathrm{p}_{3 / 2}$ 光電子スペクトルを比較し, AES は XPS よ り大きな化学シフト量であることを示している ${ }^{10)}$ 。

堤らは, 自動車用ラジアルタイヤに使用されているスチー ルコードの $\mathrm{CuZn}$ めっき部を高エネルギー分解能で AES 分 析を行い, めっき部から芯材にかけて梁さ方向に $\mathrm{Cu}$ と $\mathrm{Zn}$ の状態別の定量分析を行っている ${ }^{12)}$ 。化学状態別の定量は, $\mathrm{Cu}, \mathrm{CuO}, \mathrm{Cu} 2 \mathrm{O}, \mathrm{CuS}, \mathrm{ZnO}, \mathrm{ZnS}$ の純物質のスペクトルを 用いてオージェスペクトルのピーク分離によって行われた。

図 9 と図 10 にそれぞれの物質のオージェスペクトルを示す。 スチールコードの分析結果は, 図 11 のようになり, めっき 層とゴムの界面では，めっき中の $\mathrm{Cu}, \mathrm{Zn}$ とゴム中の $\mathrm{S}, \mathrm{O}$ が反応し, 硫化物や酸化物を形成していることが示された。

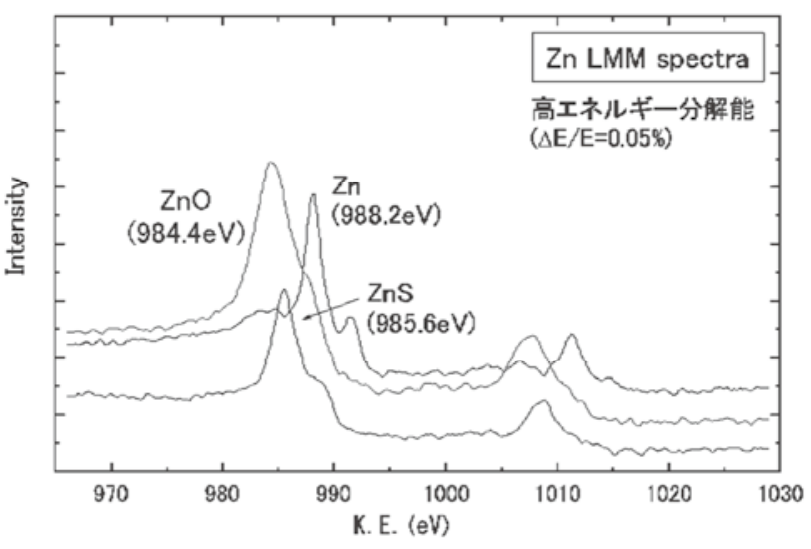

図 10 亜鉛の化学状態と Zn LMM オージェ電子スペクトル ${ }^{11)}$

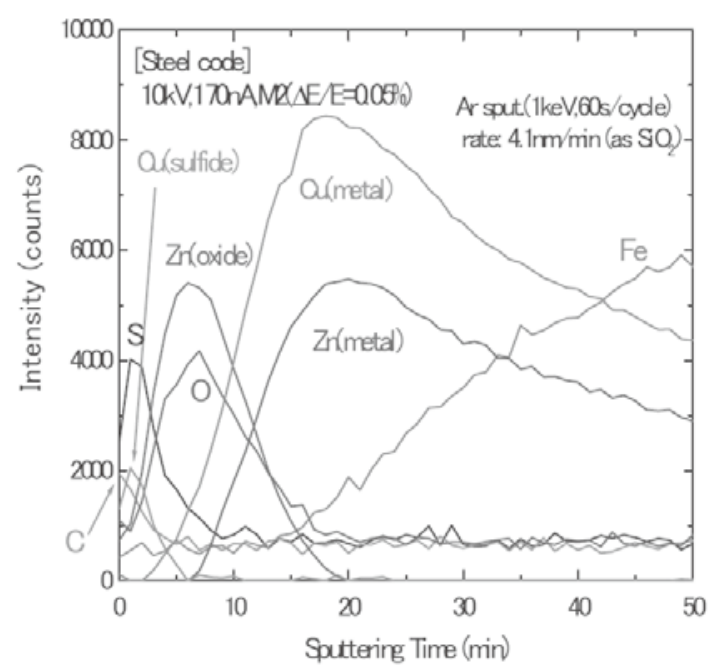

図 11 スチールコードの化学状態別深さ方向分布 ${ }^{11}$

\section{4. おわりに}

FE 電子銃を装備した AES によって数十 $\mathrm{nm}$ の空間分解能 で形態観察と元素分析が可能になったことで, 従来, 透過電 子顕微鏡に頼っていたような微小部の分析も AES で可能な 場合がある。試料の薄片加工が不要なので分析が容易にでき， 迅速に低コストで分析結果を得たい場合には有力な手段であ る。また, 高エネルギー分解能の AES は, 微小部の化学状 
態に関する情報も得られるなど他の表面分析には無い特徵的 な方法であり，応用範囲の広がりが期待できる。

材料の開発や製造に役立つ分析情報を得るために, AES は幅広いニーズにこたえる方法であるが, AES 以外にも各 種分析法の原理や特徵を理解し，それぞれの特徵を活かして うまく使い分けることが重要である。本稿で述べた AES の 原理, 特徵, 応用事例がその一助となれば幸いである。

(Received August 28, 2015)

\section{文献}

1) アルバック・ファイ(株); Handbook of Auger Electron Spectroscopy

2 ）日本表面科学会編; オージェ電子分光法(丸善(侏), 2001).

3 ）(社)日本分析機器工業会ホームページ; http://www.jaima.or.jp/jp/ basic//pdf/basic_18.pdf

4 ）堤 建一, 鈴木俊明, 長澤勇二; 日本電子ニュース, 33, 61 (2001).

5 ) 田中幸基, 祐谷将人; 特殊鋼, 2015年9月号(印刷中).

6 ) R. Kelly, D. E. Harrison ; Materials Science and Engineering, 69, 449 (1985).

7 ）日鉄住金テクノロジー(株) ホームページ; http://www.nsst.nssmc. com/

8 ) K. Tsutsumi, M. Shima, A. Tanaka ; JEOL News, 49, 59 (2014).

9 ) 広川吉之助, 福田安生, 鈴木堅市, 橋本 哲, 鈴木敏子, 薄木智亮, 源内規夫, 吉田鎮雄, 甲田 満, 瀬崎博史, 堀江 浩, 田中彰博, 大 坪孝至; 鉄と鋼, 77, 1533 (1991).

10）境 悠治; Journal of Surface Analysis, 13, 239 (2006).

11）河合 潤, 足立裕彦; 表面科学, 15, 23 (1994)。

12) K. Tsutsumi ; JEOL Application Report, (2005). JEOL EPMA Surface Analysis Users Meeting より日本電子(侏)の許可を得て転載 